\title{
A STUDY OF THE HOUSE FINCH.
}

\author{
BY W. H. BERGTOLD, M. D.
}

THE characteristic native bird of the cities and towns of Colorado is the House Finch (Carpodacus mexicanus frontalis); notwithstanding its sweet and characteristic song, it is commonly mistaken by the average citizen and visitor for the English Sparrow.

Previous to the advent of the English Sparrow in Denver (about 1894, according to the writer's notes) the only bird at all common about the buildings of Denver was this finch. Before the present extensive settlement of Colorado, the House Finch was, so far as one can gather from the reports of the various early exploring expeditions, to be found mainly along the tree covered 'bottoms' of the larger streams, along the foot hills, to a small extent up the streams into the foot hills, and possibly along the streams as they neared the east line of the state.

For the past six years, the writer has systematically and particularly studied this species, bearing in mind several problems concerning it; the data secured in this work is now published for the first time.

It seems desirable to say here that the writer alone is responsible for each and every note, observation, and conclusion given in the following paragraphs, the same having been drawn entirely from his personal studies: everything herein following is published without prejudice to past observations and conclusions.

\section{Method of Study.}

Under this caption are included the usual general observation of the bird whenever seen in and about the city, and special arrangements at the office and home of the writer, designed to facilitate minute observations, and to bring about a more intimate acquaintance with the bird.

The office is on the sixth floor of a building situated in the heart of the business district of Denver, and provided with suitable food and drinking trays on the window sill. At the house, besides 
similar food and drinking dishes, there are special nesting facilities arranged for the birds. During the first year of this special study the nesting boxes were nailed to the house wall, and were very shallow. While such boxes gave the Finches ample opportunity for nesting, and were well patronized, it was soon seen that the shallow character allowed too easy access to the nest, a condition promptly utilized by the English Sparrow, to the great distress of the Finches, and the detriment of their nests, eggs, and young. It was also soon learned that boxes fastened to the house did not lend themselves to close and rapid inspection of nests, eggs, or young. Consequently, after the first trials, such nesting boxes as were under a small sharply pitched overhanging eave, were of flat cigar boxes, placed on shelves firmly fastened to the house, provision being made to prevent the box being blown from the shelf, and the whole structure so placed that there was only enough room above the nest-box to admit a small bird, and no more. By this arrangement the boxes could be lifted off the shelf from a near-by window, and taken into the house for a brief inspection. It also gave the Finches some advantage in fighting off the destructive English Sparrow in its persistent raids on their nests.

Those nesting boxes which were placed under a broad horizontal overhanging eave were made in two sections, a smaller inner nesting box telescoping from below into a large outer box, the latter being securely attached to the wall of the house. The inner box sliding upward into the outer box formed for it a false bottom, as it were, and was kept from dropping down by suitably arranged hooks. The top of the assembled box was partly closed over by a cover, an arrangement quite necessary in order that the Finches might put up a better fight against the English Sparrow when it entered from above. These first deep boxes were provided with small holes in the sides for ventilation, but this was later found not only unnecessary, but positively harmful, as it permitted late snow or cold rains to beat in on the eggs or young, causing considerable loss of both. These deeper nesting boxes were also of advantage in preventing the young from flying too early and by the time they were able to fly from the nest to the box top (about 6 inches), they had learned pretty well how to manage their wings, and were able to go, on the first flight from the nest, to nearby 
trees or buildings with certainty and safety. During and after the summer of 1908, there were nine of these boxes attached to the house, all in pretty constant use by the Finches.

Drinking places or pans are strikingly necessary in Colorado's dry climate, and our birds visit any accessible water very frequently; hence artificial supplies of water have been peculiarly helpful in the present investigation.

The Finches soon learned that no harm was done to them when the nesting boxes were taken into the house for examination, and soon ceased to fret if a nest was temporarily absent from its usual place. Unless constantly frightened or really harmed, these birds have short memories for minor disturbances. This is well illustrated by one occasion, when a persistent fluttering in a box, located near the writer's sleeping porch, called attention to a nesting female Finch caught and entangled in some string which it had used to construct the nest, the string having become firmly entangled about the bird's foot. The bird would have perished had it not been freed, but in less than fifteen minutes after it was again building as busily as before, notwithstanding the handling incidental to its liberation. This occurrence also shows how well the House Finch lends itself to study. It is not essential for ordinary study that the boxes be taken down daily and brought into the house, as much can be accomplished by inspection with a hand mirror held above the nest.

\section{Abundance.}

In 1881 when the writer first visited Colorado, Denver was a small city of about 30,000 inhabitants, spread over a rather limited area, and built of houses and blocks of very modest dimensions. The House Finch had, however, already taken advantage of the opportunities afforded by the nooks in, and sheltered projections of, houses, barns, and other buildings, to construct nests thereon. The bird was then only fairly numerous, yet its engaging song indelibly impressed itself upon the writer's memory. In the interval since 1881, the multiplication of these birds in Denver has been enormous and it seems reasonable to assume that this increase has 
been due largely, if not entirely, to the enlarged facilities for nesting brought about by the presence of buildings erected, and trees and vines introduced, through civilization; and to a larger food supply afforded the birds, resulting from the great increase of seed bearing weeds which has followed the plowing of the virgin prairies on which the city grew. Furthermore the waste food products of this city form a large source of food for these birds, and have added to the other factors leading to the increased abundance of this species. It would appear from this that we have here another example of man's unconscious aid in the multiplication of an indigenous bird population and fortunately for Denver, this species has probably been largely, if not wholly, beneficial, thus making for the community's good.

The House Finch is resident in Denver, though some facts relating to its seasonal incidence lend color to the idea that it may be locally migratory. During August and September of each year there is a noticeable diminution of Finches about the city. This is the time when the burdens of nesting and raising of young are practically over, permitting young and old to flock on the prairies to feed on weed seeds:- numerous records of flocks seen in the suburbs about this time, and later, would confirm the above idea.

It is exceedingly difficult to determine if the same individuals remain in one's neighborhood throughout the entire year. During the summer of 1908 an effort was made to throw light on this question. Sixteen young birds, all raised in the writer's nesting boxes, were tagged with a light brass band, the same having been placed about the right tarsus of each bird before it left the nest. With the exception of one, which was found crushed in the alley the day after it flew from the nest, none of these 16 birds was ever again identified about the premises. This might be taken as meaning that the young did not remain permanently about the nest neighborhood, but it may be that such tagged birds did remain in the neighborhood, but were undetected.

In the summer of 1909, several young birds were tagged with brass bands on the left tarsus, and in 1910 some with brass bands on both tarsi, with the hope that such marking would aid in determining how old a Finch might grow to be if left to nature, and all the vicissitudes of bird life. This tagging has shown definitely 
that some, at least, of the Finches remain in one's immediate vicinity the entire year; e. g., $\sigma^{\top}$, marked October 2, 1909, was seen all the following winter, and again in the succeeding spring, and another, $\sigma^{7}$, marked by bands on both tarsi, has been noted about the office building for more than two years.

\section{WiNTERING.}

Winter in Denver seems to have no terrors for this species. It appears to the writer that the cold season does not trouble the House Finch much so long as the bird is well fed, though many, doubtless, suffer frosting of feet during extremely cold spells, resulting in mutilations referred to later on. The birds roost at night, whenever possible, close to buildings, in vines next to a wall, in a nook or on a moulding under an overhanging eave, and in the folds of awnings, for which places the birds have many fights until all are located for the winter, each going to its accustomed place a considerable time before sunset. The young birds sleep in trees after leaving the nest. They have never been observed to sleep two or more together, but appear, on the contrary, to desire separate places, each by itself. It has seemed odd to find that the birds never use the nesting boxes to sleep in, after the nesting season is over. In December they go to roost early, 4.15 P. M. and sleep with the head under the wing, puffed up like little feather balls.

\section{Census.}

Can one form any definite idea as to how many House Finches there are in Denver? This question imposed itself on the writer early in this study, because of the relation of this species to the English Sparrow, and while it is self-evident that any estimate along these lines must be approximate only, it is however, not without interest to try to answer it.

There are in the city of Denver 3500 blocks whereon are to be found buildings of one kind or another. If two Finches are allowed for each block there would appear to be 7000 Finches in the city, a number seemingly reasonable as a minimum estimate. At one 
time during the summer of 1908, at least fourteen pairs of Finches were known to be nesting in the block in which the writer lived; thus there were twenty-eight Finches living in this block at that time. It is possible that the unusual nesting facilities at the writer's house may have increased the Finches in the block beyond normal numbers, yet a careful survey of many blocks in other parts of the city justified the writer in feeling that the number of Finches in his block was what one might call "average common." This would give us another estimate, counting only the built up blocks, to wit, 98,000 for the entire city. The writer has actually counted in April more than one hundred Finches congregated on the telephone wires leading to one building, near his office, a structure ornamented with many ledges, lintels, arches, etc., and lending itself well for night lodging places for the House Finch. This date is well on in the early incubation period of the year, and one feels justified in assuming that these birds were not young of the year, or old birds gathered together from a wide area to roost only, but were most likely males going to rest near their nesting locations. This is, furthermore, made more probable by the fact that all of these birds seemed in full spring song, characteristic, practically, of the male only. There could not have been less than 200 birds about this building at the time mentioned, and there were almost as many more on the building on the opposite side of the street, showing that these birds are extraordinarily abundant about the business parts of the city, an abundance which can well compensate for any possible scarcity in the outskirts, though it is readily evident that in the outskirts too, the Finches are quite numerous. If we estimate 200 Finches to each 'built on' block, we would have a Finch population of 700,000 , a number to be considered as a maximum, and probably a considerable overestimate, though the writer is by no means convinced that it is actually an overestimate. Averaging the Finch population in another way, one can say that there are four Finches for each of the 35,000 houses (or other buildings) in Denver, resulting in a total of 140,000 House Finches in the city.

No portion of the territory within the corporation limits is without its Finches, and after studying the question with care for years, and considering every way of making an estimate, the writer feels 
that it is very reasonable to assume that there are ten House Finches to each platted block within the city, which would give a total of 130,000 Finches, there being 13,000 platted blocks in the city, 3500 of which are built on; this estimate of 130,000 House Finches for the city of Denver is probably far below the actual number.

\section{Song.}

Both sexes sing, though the female's attempts are modest and rather infrequent. That the females sing is indisputable since nesting females have been noticed singing, an observation which precludes mistaking an immature male's singing, for a female's attempt at song. The female's is, however, a weak imitation of the male's vigorous and sweet song, which is best and richest, as with other song birds, during the breeding season, yet there is no month of the year when this song is not heard. During the cold months the birds are comparatively silent but they frequently burst into song on bright sunny winter days, which, with us in Colorado, are very common. The association between these clear bright mild winter days and the singing of the Finches is too obvious to be overlooked. The song is poured forth in volumes while the bird is on the wing, and also when at rest, and reminds one in parts, of that of the Pine Finch. From the middle of January onward, the singing increases with the lengthening days, hushed now and again by extreme cold, and this generous song makes the bird a delight and a joy, one to be harbored and protected.

By attracting the birds to one's windows, one comes so closely in touch with them that opportunities for detailed study are unsurpassed, while the bird's abundance and fearlessness give one the most intimate acquaintance possible. Furthermore, the varied calls and notes of both sexes are of exceeding interest, heard to great advantage in this way through their propinquity. There is a distinct and recognizable difference in the alarm note over the sight of a dog or a cat if it be near the drinking place, and the alarm when one examines the nest. The writer has learned to know when the young are ready to leave the nest by the peculiar coaxing notes of the old birds. During nest building, the male often feeds his busy 
mate, as he would a young bird, and at such times the notes uttered by the female are peculiar to this part of the nesting habits. During August and September the song is at ebb, but starts afresh, on a subdued scale, in October.

The young of the year have frequently been heard trying to sing in late summer, a song small in volume but with unmistakable characteristics.

\section{Foop.}

The House Finch will eat almost anything vegetable, though it prefers seeds, and experiments with different seeds show that hemp is selected to the exclusion of all others. Nevertheless it feeds in our streets and alleys, gathering bread crumbs, eating from pieces of bread, apples, oranges, and, in fact, from almost any piece of table refuse. It will consume large quantities of fat, more especially suet. In winter when the ground is unusually deeply covered by snow, these birds wander far and wide over the prairie and vacant city lots, eating weed seeds, particularly those of the so-called Russian Thistle (Salsola tragus). It was, to the writer, a most satisfying discovery to find that the nestlings were, whenever possible, fed as soon as hatched and thereafter, on dandelion seeds. Each succeeding year has confirmed this observation and young birds not more than two hours out of the egg have been noted with crops stuffed to repletion with dandelion seeds. At this period of the bird's growth the neck-skin and the crop covering are almost wholly transparent, so much so that one can readily distinguish the dandelion seeds within. The old birds are to be seen at this time busily gathering these seeds for the nestlings, selecting those dandelion blossoms which have matured but are not yet open enough to permit of the seeds being dispersed by the wind. Such blossoms are deftly dissected by the old birds, and each seed taken from the blossom, the pappus being nipped off close to the seed. To insure certainty to the correctness of this observation, the writer has examined the crops of several nestlings killed by English Sparrows, and has been able to say definitely that the crop content, in these instances, was formed wholly of dandelion seed.

If not fed on dandelion seeds, the nestlings are given such food 
as the old ones usually consume but the writer has never detected any animal food in the crops or stomachs of House Finch nestlings. This Finch has never been seen feeding from the horse manure of the streets.

The House Finch exhibits, in common with many other birds, a fondness for maple sap, sipping it as it oozes from the cut branches of a spring pruned tree. The only objection my friends hereabout have against the House Finch is that it eats in the spring, leaf and blossom buds from bushes and trees - for example, lilac bushes and apple trees.

\section{VARIATION.}

The tameness of the bird and one's proximity to it lent by this method of study make it possible to note and realize the great and marked variation to be found amongst the House Finches: one can learn, not only to recognize different individuals by some peculiar differences in color or marking, but can also notice and recognize shades and extent of color that have been spoken of, and described as forming various races of this species.

This impresses one as though there were spread out before him a large series of skins to study; one feels much as a closet naturalist must feel when he takes in hand such a series and has the satisfaction of elaborating a new geographical subspecies. The extremes in color of feather, bill, tarsus and foot, and the presence or absence of tail emargination become so patent through one's study of the bird in this way that, though these are here seen in birds known to be all of the same subspecies, one is almost persuaded to believe the birds are specifically different. One is impressed, too, by the differences in color, pattern and marking in birds coming from the same brood. Mature males have been seen with bright yellow throats and rumps, and every shade in the mandibles has been seen, varying from coal black to a gray so light as to be easily mistaken for white.

The more one studies this interesting bird, noticing its extreme variability, the more one muses over the validity of species, realizing more clearly than ever before that species exist for man only; or, if one wishes, one can feel that one is in the presence of the making of species.

In the course of these observations, several birds have been 
noticed showing distinct melanistic phases, one female being almost black above, and not from city soiling, as the bird was still black after bathing: as mentioned below, an albino female has been seen during two succeeding seasons, having returned a second time to successfully build a nest in the locality where first observed. A female with a long decurved upper mandible has been watched through several months. This mandible was shaped very much like that of a Cross-bill and was probably not deformed through injury as it closed perfectly in apposition to its fellow of the under side, and was perfectly functional. It may well have been an example of mutation.

Many characteristics, other than physical, of each individual come to light as one watches the birds at close range. Many females are quite tame from the onset, and become steadily more so, allowing one to examine them with a mirror overhead as they are setting, showing no alarm, and even some degree of curiosity. The quarrelsomeness of some, and the gentleness of others are especially patent. The water dishes are as often desired for bathing as for drinking, causing as many disputes over the bath privilege as the birds have over food in the feeding trays. Some are so tame that they come through the open windows into the office during severely cold weather, and perch on the steam radiator which is next to the window sill.

\section{Mating.}

The writer suspects that this species mates permanently: it is apt, in all seasons of the year, to come to the food and drinking dishes in pairs. After one becomes well acquainted with this species, one learns that a series of indescribable notes and chirrups betokens a mated pair, and these notes have been heard many times outside the usual mating season, $i . e$., in the late fall and winter. It is a common thing to see a pair examining nesting boxes, and other eligible nesting sites, in December and January. In the winter of 1906-1907, a pure albino female Finch was observed on the writer's home premises, accompanied by a normal male, which paid particular attention to the albino, being, without doubt in the writer's judgment, the latter's mate, notwithstanding the distance of the ordinary season for pairing and nesting. 


\section{Nests and Nesting.}

The House Finch nests in vines about houses, in sheltered corners and awnings of buildings, in baskets hung on houses, and, in fact, in any place of vantage about a building. It also, though rarely, builds in trees, as high in one instance as twenty feet above the ground; in bushes; and in years past (1894) when the electric arc street lights were covered by a conical metal hood, a number of nests were seen on the cross piece under the hood. Nests have been observed in globes, when partly broken, surrounding incandescent lamps hanging under verandas and portescochères. These nests were frequently found in very noisy and conspicuous places, i.e., the busy entrance to a large hospital. A pair had a nest, during the past spring, in one of two old-fashioned square lantern-shaped entrance lamps on the University Club, in each of which were two incandescent lamps burning brightly until past midnight. The incubating female was not disturbed in the least by this light, nor by the numerous visitors to the club going by her nest.

The writer has only once noticed the species use an old nest of some other species for nesting purposes, in which case a pair of House Finches relined an old Robin's nest and used it to raise a brood. It will thus be seen that there is a considerable degree of flexibility in the House Finch's nidification traits, a flexibility which probably has helped very largely toward the bird's great increase in Denver.

The writer is fully convinced that nesting bears a large relation to the weather conditions, being controlled largely, perhaps entirely, by the temperatures prevailing over a more or less extended time. Very frequently in Denver, October and November are remarkably mild, and during such mild spells young Finches, in pairs, have been observed inspecting the bird boxes on the house, and on a few occasions in October and November a pair of young of the year have been seen making abortive attempts at nest building. This suggestion - the effect of warm weather on the nesting instinct, is made more probable by the actions of the birds during warm spells in mid-winter, when the males begin to sing vigorously, the song 
exhibiting many easily recognizable nuptial characters - all these indications of the awakening of the nesting instinct are at once silenced if cold weather supervene. Cold weather has a positive deterrent effect on egg laying, a fact clearly established by the writer's records. On the other hand pairs of House Finches, unquestionably mated, have been observed looking for eligible nesting sites in every month of the year, not excepting the period from September to February. The earliest active nest building noted by the writer was on January 30, and the latest July 23; while pairs have been noticed gathering material as late as December 22 , these attempts have been classed, however, by the writer as due to a fleeting spell of warm weather.

The birds grow very tame if the nest be closely associated with man and his doings: they seem to be bothered in no way by slamming of doors or by passers in and out of a door close to a nest. The nest is a shallow cup-shaped affair, roughly about four to five inches in diameter, which varies, however, according to the space in which it is built, and has a depth within its cupping of from two to two and a half inches. If built in a box it never completely fills the whole of the floor space unless the box be very small otherwise the nest will be of the usual diameter, and placed, in the majority of cases, in the end of the box farthest away from the light. The materials used in nest building vary according to location: one found in the business district was made entirely of dried freshly cut grass, evidently gathered from the lawns surrounding the municipal buildings, and had a lining of cotton batting. Another nest from the business district was made of rootlets, cow hair, and also lined with cotton batting.

Nests found in the outskirts of the city have the outer portion made of straw, hair, string, small twigs, weed branches, grass and rootlets, and have as a lining some good non-conductor of heat, $i$. e., cotton wool or string. One nest was built over a large mass of wool which seemed to have attracted some variety of fly, which later had deposited its eggs in the wool, producing maggots that did not bother, so far as one could determine, the young finches growing above them.

One can expedite and encourage the nest building by putting fine straw or dry grass in the nesting box, arranging the material 
roughly in the shape of a nest just begun. The first nests of the year are usually built very slowly, three to six days being consumed in the work, which is done wholly by the female, though the male often brings pieces of nest material, which are, however, never accepted by his mate. This performance of the male always impresses one as being a 'bluff.' He dances constant attendance on the female as she works, cheering her continually with vigorous song, at its best at this time. Later in the season a nest, if it be what one may term 'an emergency nest,' may be completed in a single day, and an egg laid in it on the second day.

After a nest is finished, if it be not an 'emergency nest,' the builders almost invariably leave the neighborhood and are not seen again for a few days, at the end of which absence they reappear, and egg laying begins. If the birds be undisturbed, and the old nest left in situ, it may be used to rear a second brood, without its being renovated in the least; but this use of an old nest is not usual. More often an old nest, if used for a second time, is partly covered by a new one, to avoid, it may be, insects, or the soiled condition of the old one. In only one instance has the writer seen the same nest used for three successive broods. On several occasions a new nest has been built over an old one, in which there were abandoned eggs: whether or not the builders of the first and second nests were the same birds, the writer is unable to say. Vigorous nest building begins early in March, unless the weather is too severe. The earliest date on which a completed nest, with an egg in it, has been noted was March 12, though there were many nearly completed nests in the same neighborhood on the same date, or earlier. By the last of March, nesting is in full swing all over the city, but the flood tide of nidification is in April and May (taking the egg laying as an index), there being little difference between these two months, as the following table will show, the data being from the nests about the writer's home premises:- 
TABle No. 1.

Number of nests completed and containing at least one egg.

\begin{tabular}{l|c|c|c|c|c|c}
\hline & 1906 & 1907 & 1908 & 1909 & 1910 & Total \\
\cline { 2 - 3 } March & - & 2 & 2 & 2 & 2 & 8 \\
April & - & 4 & 9 & 0 & 5 & 18 \\
May & 2 & 5 & 6 & 4 & 2 & 19 \\
June & 3 & 3 & 3 & 2 & 2 & 13 \\
July & 2 & 1 & 2 & 3 & 0 & 8 \\
Unrecorded & 1 & 1 & 0 & 0 & 0 & 2 \\
Total & 8 & 16 & 22 & 11 & 11 & 68 \\
\hline
\end{tabular}

The materials used in nest building are not always gathered in the neighborhood of the nest, for the females often go considerable distances for nesting stuff, though suitable material could be gathered closer at hand.

The chances are that a pair uses an old nest more than once, though this is not easy to determine, simple as it might seem. One pair, the female of which had a white feather in its tail, selected a new site for their second, and also for their third brood, which establishes, in any event, that this easily identified pair did not use the old nests for new broods.

On several occasions, when English Sparrows have so harried a pair of Finches as to stop incubation before the writer could dispose of the invaders, the same Finches, presumably, have built a second nest over the first one and its eggs; that, however, the builders of the first and second nests were identical, the writer has never been able to determine beyond doubt. Four attempts, extending over a period of sixteen weeks, at nest building in the same box were observed by the writer in 1908, the birds seemingly being identical in all four attempts, but not identified with certainty. One and the same pair, identified positively, has been detected building in one box for a while, only to stop and begin anew in another; probably due to interference by English Sparrows. 


\section{EGGs.}

The average number of eggs in a set estimated on sixty-six sets, having a total of two hundred and eighty-one eggs, is four plus, the largest being seven, and the smallest two, the latter however may not have been a completed set, though it went on to full incubation. In emergency sets, $i$. $e$., complements of eggs laid after a previous set had been destroyed by English Sparrows or storms, smaller numbers prevail.

The average weight of a first egg was found to be 36 grains (13 weights averaged), the extremes of weights being 32 grains and 40 grains. Some sets are extremely variable in the weight of the eggs therein, one set of four eggs giving weights of $32,33,35$ and 35 grains, while another complement of eggs weighed $35,35,35$, 35 and 36 grains respectively. The average length was .77 inch, and the diameter .54 inch, the extremes in length being .81 inch for the maximum and .68 inch for the minimum, while the extremes in diameter were .57 and .51 inch respectively.

The earliest date on which an egg has been detected in a nest was March 12, and the latest (counting the date on which the egg was laid) was July 27.

After a female begins to lay, one egg is laid each day until a set is completed. It is quite rare that the daily eruption of an egg is disturbed or intermitted; in 68 sets recorded during five years there have been but two in which this orderly succession of an egg a day has not obtained, and it is quite possible that on one of these occasions the interruption was due to the sudden onset of extremely cold weather. So far as the writer has been able to determine, the eggs are always laid at night, $i$. e., between the hours of 7 P. M. and 7 A. M., many nests having been examined repeatedly at short intervals during the day with special reference to this particular point.

With the larger sets (five or more), one often finds an egg outside the nest, presumably accidentally crowded out, because of lack of room. Several times infertile or undeveloped eggs have been found in the box outside the nest, the other eggs of the set having gone to successful incubation. Whether the old or young birds have accidentally pushed out such eggs, as they move about in the nest 
is not determinable. The writer suspects that the old birds may remove from the nest, eggs which have failed to hatch, because such eggs have frequently disappeared when the nest has in no way been disturbed by English Sparrows, which would be the only other cause in explanation of this disappearance.

The female has a peculiar and unmistakable cry when laying, a call which is answered promptly by her mate. The writer has frequently been led to discover new sets of eggs in a nest through hearing this peculiar 'egg cry' of the laying female. The female also calls to her mate in a different, yet characteristic, way when incubating. She is then often fed by the male, the feeding being precisely similar to the feeding of a young bird, even to the fluttering of wings, etc.

The average length of incubation is fourteen days: occasionally it may be a few hours or even a day shorter, but more frequently it is longer. In one set the first egg laid apparently took fifteen days to hatch, and the fourth egg seventeen days, the other two eggs of this set being failures, one from infertility, and one dried after being partly developed.

It is somewhat difficult, in studying the incubation period, to estimate the amount of incubation effected by the laying female. In some sets the first egg laid can be seen to be partly incubated before the whole set is completed, taking the newly formed red blood channels which show clearly through the shell in the developing ovum as an index of incubation. This may, and probably does, explain the irregularity which has frequently been noticed in the hatching of a set of eggs; almost every possible combination of hatching having been noted - all on the same day, though this is not common; two on one day and the remainder at regular intervals etc., etc. The female, while incubating, has been seen during daylight asleep on the nest. The eggs sometimes undergo a surprising amount of cooling without being spoiled. One set, when partly incubated, was successfully hatched after being uncovered all of a cold rainy night, the female having been frightened from the nest at about 11 P. M., not returning until daylight. Several sets have been hatched despite the occurrence of several snow storms during incubation. An attempt was made, several times, to mark and number each egg as laid, in the end to determine 
which egg was hatched first, but each effort, except one, was a failure because the pencil marks became blurred or effaced by the rolling of the eggs in the nest as the setting female moved about.

This method of investigation, by marking the eggs, has not been pushed as far as might have been possible, because of the fear of breaking the eggs, which accident happened once in the early attempts at marking. The writer has also been unable to determine whether the largest or the smallest egg hatched first, or whether the size of the egg bore any relation to the length of incubation. In the single exception mentioned above, the egg laid first, hatched first. It is possible that the eggs, as laid, could be colored by analine dyes, and thus be distinguishable one from the other; but this method was not used through the fear that the dyes might be detrimental to the development of the eggs. Only once, during five years of systematic observation on 68 nests, have empty egg shells been found in a nest, an observation which may reasonably be held to show that the old birds remove the empty egg shells, as they do the fecal sacs during the first days after the eggs are hatched. Two broods are probably raised each summer, and, on one occasion at least, three were raised by the same female.

The record of this particular female is interesting: the first egg of brood No. 1 was laid May 14, of brood No. 2, June 23, and of brood No. 3, July 9 . In brood No. 1 there were five eggs, in brood No. 2, four eggs, and in brood No. 3, three eggs, this diminuendo scale meaning, perhaps, a gradual slowing of the ovarian energy for that year. Of these twelve eggs, one was infertile, seven were hatched successfully, and the nestlings left the nest in due season; and though the four of the second set were hatched successfully, English Sparrows raided the nest, and killed all the nestlings when they were two days old. It is highly probable that this female was stimulated to raise a third brood by the early loss of the second one.

\section{INFERTILE EGGS.}

The number of infertile eggs out of a grand total of 283, was 25 , a percentage of infertility of about 9 . It is rather difficult to establish a certain index of infertility, and, to be safe, the writer considered as infertile only such as could not have been chilled, or such 
as failed to hatch when others in the same nest were successfully incubated. All eggs which failed to hatch were examined to determine if any development had occurred, and when any least trace was found, such egg was not counted as infertile. The infertility varied considerably from year to year as the following table will show:

Table No. 2.

\begin{tabular}{l|l|l|l|l|l|l} 
& 1906 & 1907 & 1908 & 1909 & 1910 & Total \\
\cline { 1 - 2 } $\begin{array}{lllll}\text { Sterile eggs } \\
\text { Total laid }\end{array}$ & 1 & 8 & 3 & 9 & 4 & 25 \\
\cline { 2 - 5 } & 33 & 64 & 87 & 52 & 47 & 283 \\
\hline
\end{tabular}

The male feeds the young for a considerable period after they leave the nest, often so long that he will also be feeding at the same time the young of a second brood. The female is most devoted to her nest, leaving it with extreme reluctance, and returning as soon as an alarming disturbance ceases. The nest is kept under close surveillance, and a female may even show signs of anxiety if an empty nest (after the young have flown) be examined. The incubating bird will stay on a nest under very distressing conditions, i.e., during a severe snow storm; and on one occasion a female was noticed brooding a nest full of young which had frozen during the previous night.

\section{Feathers.}

The feather development and growth occur with amazing rapidity, even twenty-four hours making surprising changes, especially during the first few days after hatching. The appearance and growth of the various feather tracts differ, apparently, in different broods and individuals. It is approximately as follows:the young up to the fourth day seem naked, but are really partly covered by a minute down which appears in streaks, there being four lines on the head, i.e., one along the skull in the long axis of the body, one over each eye, and one over the occiput, transverse to the long 
axis of the head. There is also one along the dorsum of each wing, one over each scapula parallel with the vertebral column, an interacetabular dorsal patch, a streak down the outside of each thigh, and a sternal streak which bifurcates, one fork going under each wing, and on the second day an interscapular vertebral streak appears. All these areas grow rapidly and soon appear to coalesce; and by the fourth day the body seems to be covered all over with down, except the belly, and, by this time, the wing quills are just budding. On the fifth day, the wing quills are one eighth of an inch long, while the back and side streaks of down show a stubby growth of feather tubes. The wing quills, on the sixth day, are three-eighths of an inch long, the tail feathers are one quarter of an inch long, and the back and neck stubs are now clearly distinguishable as feathers. On the seventh day, the wing feathers are five eighths of an inch long, but are not wholly delivered from their casings, and the shoulder stripes show as true feathers. On this day, the wing, tail and back feathers are long enough to be preened by the young bird. On the ninth day, the back is entirely covered by true feathers; and on the twelfth day, the whole bird appears feathered as an adult, with, however, this difference, that a good deal of the original down persists, and stands out beyond the true feathers, most noticeably on the head. It was of especial interest to the writer, while taking notes on the feathers of this bird, to see how slowly and how late the head became covered, a condition which may perhaps be taken as a tendency to persistence of the primitive avian pterylosis, in which the head was long naked. (Scott - Introduction to Geology, p. 698.)

\section{Nestlings.}

The young remain about fourteen days in the nest, which is kept perfectly clean by the old birds for four or five days after the eggs are hatched.

When the young birds have developed enough to voluntarily move about, and arrange themselves in the nest, which usually is about the fifth day after hatching, the nest edge then exhibits the first signs of fecal soiling, which comes about in a manner common 
to many other nestlings, that is to say, the young birds void backward over the nest edge, after each feeding, leaving the nest centre unsoiled. The young are fed by the parent bird during the whole of nest life by regurgitation. If the season be that of dandelion seeding, which in Denver is a continuous performance from April to November, the crops of the nestlings are seen to be full of dandelion seeds. When the nestlings are very young (one to three days old) the regurgitation act of the parent is very prolonged; indeed it is very much longer at this time than when the young are more fully developed. Both old birds share the work of feeding the young, and the intervals between the feeding are comparatively long, much longer than with nestlings fed on animal food, as a Robin, for example.

An interval of fifteen or twenty-five minutes between feeding visits by the old birds to the nest is not at all unusual. This may be due to the obvious fact that it takes longer to gather a crop full of seeds than it does to get a bill full of worms. The old bird invariably goes to the drinking dish for water, immediately after feeding the young. Different pairs vary very much in their attentions to the young and it is noticeable that the old birds are less assiduous in feeding the young toward the time when they ought to leave the nest, a neglect which may tend to make the nestling venturesome and leave the nest. The newly hatched birds make no noise, and not until about the third day can one detect any sound coming from them; and then it is but a faint peeping, which, however, rapidly increases in vigor and strength, so that on the seventh day in the nest, the young birds make considerable noise when the old birds visit them. If a bird only twenty-four hours old be placed outside the nest, it will crawl about using its wings as a pair of anterior legs and a nestling three days old will, if placed on the nest edge, crawl back into the nest, and arrange itself according to a fixed way, rump in, and bill extending toward or on the edge of the nest. The young preen themselves quite early during nest life, as they have been seen arranging and cleaning their feathers when seven days old. During the first three days after being hatched, the young seem to have closed eyelids, but a close and careful scrutiny reveals a narrow slit through which the birds probably notice their surroundings. 
Not infrequently a very small nestling (i.e. 24 hours old) has been found uninjured outside the nest proper, it is possible that the old bird in trying to remove egg shells may have pulled the little bird out of the nest.

The old birds remove the fecal sacs as they are voided by the young after each feeding, up to the fifth day, the nest remaining perfectly clean during all these days. From this time on the nest edge becomes progressively more and more encrusted with the fecal sacs which are voided by the nestlings over or on the nest edge. If the nestling be taken from the nest and fed by hand, an excremental sac is voided at once after the food is swallowed, the bird backing as though going to the nest edge, the action impressing one as being due to an irresistible impulse. One can see at once, from the soiled edge of a nest, if it has sheltered a successfully raised brood. On several occasions one of a brood has died in the nest, and afterward disappeared. It is assumed by the writer that the old birds have thrown out the dead one, but he has never been able to verify this assumption; on the other hand, dead nestlings have been found mummified in a nest in which the others of the brood have gone to full development.

The nestling is able to hold up its head and open its mouth as soon as it is free from the egg and dry. It can squirm about with considerable force within two hours after hatching, and when two days old will crawl feebly about and try to place its head well up on the nest edge. When eight days old, the young ones are attentive, vigorous and alert, but not yet timid, and if the nest be taken down for examination the little birds will squeak and open their mouths to be fed. If lifted from the nest at this period, they cling most tenaciously to it with the feet, and when put in the scale pan to be weighed, they are very active and crawl about in a lively manner.

At this time, too, they arrange themselves very definitely in the nest, each seemingly having its place, and each tries at once, if disturbed, to get to its place and rest its bill on the nest rim. On the tenth day, they seem ' conscious' of their surroundings, appear to be 'studying' the nest, and each other, and have acquired a noticeable degree of timidity. From this time until the nest is deserted, they move about in it, mounting to the edge where they frequently stand and energetically use the wings in a fanning man- 
ner, an 'exercise' which undoubtedly leads to growth and development of the great pectorals. Many can fly well on the twelfth, and some leave the nest on the thirteenth day, though the time of leaving the nest is quite irregular. All may leave on the same day, which is most commonly the fourteenth, yet some remain in the nest until the sixteenth day after hatching. One finds almost invariably, in a large brood of five or six, that one or two of the birds have gotten a good start on the others through having been hatched earlier, and that such birds fly before the others do.

Without an exception, the writer has found that the nestling's note changes, a day or so before its first flight, from the peeping sound characteristic during nest life, to the cry of a young bird able to follow its parents, and the writer has been warned a number of times by this unmistakable change in note, that some of the young in his nesting boxes were ready to leave them.

About this time also, the young birds take instant heed of the old bird's cry of warning, if danger be near. The first flight is frequently a long and vigorous one, many nestlings having been seen to leave the nest and at once fly two hundred feet to a tree or house. Several times when this has occurred the little one has been accompanied in its initial flight by the parents, both old birds flying as close to it as possible. Contrary-wise, many times these nestlings on the first attempt at flight will drop to the ground. Under such circumstances they crawl into corners, or under bushes, or amongst leaves. How they there escape the ubiquitous cat is hard to understand, yet they do, and one can watch them about one's yard gaining strength and self-reliance from day to day. They always try, by climbing, to get as far from the ground as possible and by dint of short jumps and flights, mount from ground to bush, bush to fence, and fence to tree, where, once well established, they remain several days, being fed regularly by the old birds. It is astonishing how much cold and exposure, soaking by rains and wet snows, these young birds will stand. The mortality is very great, however, after such exposure, especially if it comes soon after they leave the nest. Many perish, too, by hail storms.

When one can study daily several developing broods of House Finches, the individuality displayed by particular nestlings is 
startling: one, for example, will early show a tendency to be a 'fighter,' resisting handling, and pecking one's hand, while all the rest in the brood may be quite submissive. The color-identification scheme, hereinafter to be described, often permits one to follow and study a certain bird for some days after it leaves the nest, and has made it possible to ascertain that the young birds feed themselves at least as early as seven days after leaving the nest, though at this time they still follow the parents about, begging most persistently to be fed. Hence it follows that, if a young bird were thrown wholly on its own resources at this time, only five weeks would have elapsed from the laying of the egg until the embryo had become fully grown and able to shift for itself, this period of five weeks including two weeks of incubation, two weeks of nest life, and one week of post-nest life. It is surprising how large a number of broods will take just about this period for all their members to mature and shift for themselves. The progress of these events seems swift to the writer, inasmuch as the House Finch cannot be considered in any way precocious.

It has seemed to the writer that those birds hatched last in the brood are not so vigorous as those out first; it is possible that this notion may have arisen in the writer's mind because the first hatched have a considerable start in growth and vigor by the time the last ones break through the shells. This notion is not supported by the data accumulated by weighing the developing nestlings, if weight be taken as a criterion of vigor.

The combination of cold and wet is most disastrous to the young, and the writer has often put them from the ground into bushes during cold rainy nights, covering the overhanging branches with newspapers, giving him the satisfaction of saving several young birds, while those not covered have perished. The young soon learn where the food trays are located and go to them often, stuffing themselves to repletion.

There is a great deal of difference in the color pattern of the young birds in a given brood, one having the breast and belly markedly streaked with blackish, while in another these areas are almost pure grayish. The back may exhibit parallel variations. Once all the young in a nest of four were thrown out of it by English Sparrows; three had died before being discovered, but the fourth 
seemed to recover fully on being warmed and sheltered. It was put into another nest, the young of which were of almost identical age with it, in the hope that it might be adopted and fed by the old birds of the second nest. They, however, paid absolutely no attention to it and it perished. The young of the year are often, by September, distinctly reddish on head and throat and if we assume such birds to have been hatched in the previous April, it becomes apparent that this secondary sexual character appears within the first six months of life.

\section{Special Detall Study.}

Comparative physiology is of interest and importance both to the biologist and to the zoologist. With a desire to furnish data to both, and in the end that some light might be shed on the nutritional processes of developing young birds in a wild state, a scheme of weighing young House Finches from day to day was undertaken by the writer. There are in the literature of ornithology records on the weight of young birds, the daily gain in weight of such young birds, and the amount of food consumed by them - facts appertaining especially to young Robins in captivity; but there are no such facts known to the writer relating to free wild birds. In order to learn something concerning the weight of a fresh laid egg, the weight of its embryo on hatching, the daily gain in weight of a nestling, the weight of the same bird on leaving its nest, and, finally, the weight of an adult bird of the same species, the writer carried out an interesting study bearing on these points.

With House Finches nesting in boxes, as described above, it is extremely easy to take a nest once a day, into one's house, and examine or weigh the eggs or young, without in the least interfering with the regular process of incubation or feeding.

In order to identify each bird in a particular nest, each one was marked somewhat as follows:- by using analine dyes dissolved in alcohol such birds could be colored in areas, on parts, and with such colors, as one desired; for red, fuchsin, and for blue, methylene blue was used. These dyes are readily soluble in alcohol, which quickly evaporates when applied to the young bird, and does 
the bird no harm. The first bird hatched had its right thigh and side colored red, one or two applications sufficing for the whole period of nest life: the second bird had its left thigh and side stained blue, the third its right thigh and side stained red, and its left thigh and side blue, and so on.

Combinations of parts and colors numerous enough to identify several birds will readily suggest themselves to the reader. The plan worked admirably, and made it possible for the writer to follow a young bird's career from its 'hatching' until some time after it left the nest. In determining the weight of egg or bird, it was placed in the pan of an accurate balance, and the weight recorded in grains (avoirdupois). Grain weights were used, not through choice, but because they are most familiar to English readers, and most easily carried in mind by them. We have already seen that the average egg weight is 36 grains, and that the extremes were 32 and 40 respectively. It then became necessary to secure the weights of adult males and females for purposes of comparison: the only ways to learn these weights were, either to catch parent birds which were nesting about the house, obviously interfering with the study of the young in the nest, or to kill old birds known not to belong to a box nest; and the writer was unwilling to employ either of these means. Fortunately, however, an adult female, known not to belong to a box nest was caught by accident, and was found to weigh 289 grains, which is the only datum in the writer's possession to use as an adult normal. One young bird, able to fly well, was caught on the premises, and, on examination, proved not to have come from any of the study nests. It weighed 259 grains. Before it was liberated, its breast was marked with bright red, through which characteristic it was afterwards easily recognized. It lingered about the premises for over three weeks.

Two nests of young House Finches, both sets of eggs hatching almost simultaneously, were selected and studies as to the initial, the daily gain in, and the final weight of their nestlings. The following table gives the data thus obtained, together with the meteorologic conditions prevailing during the period of study: 


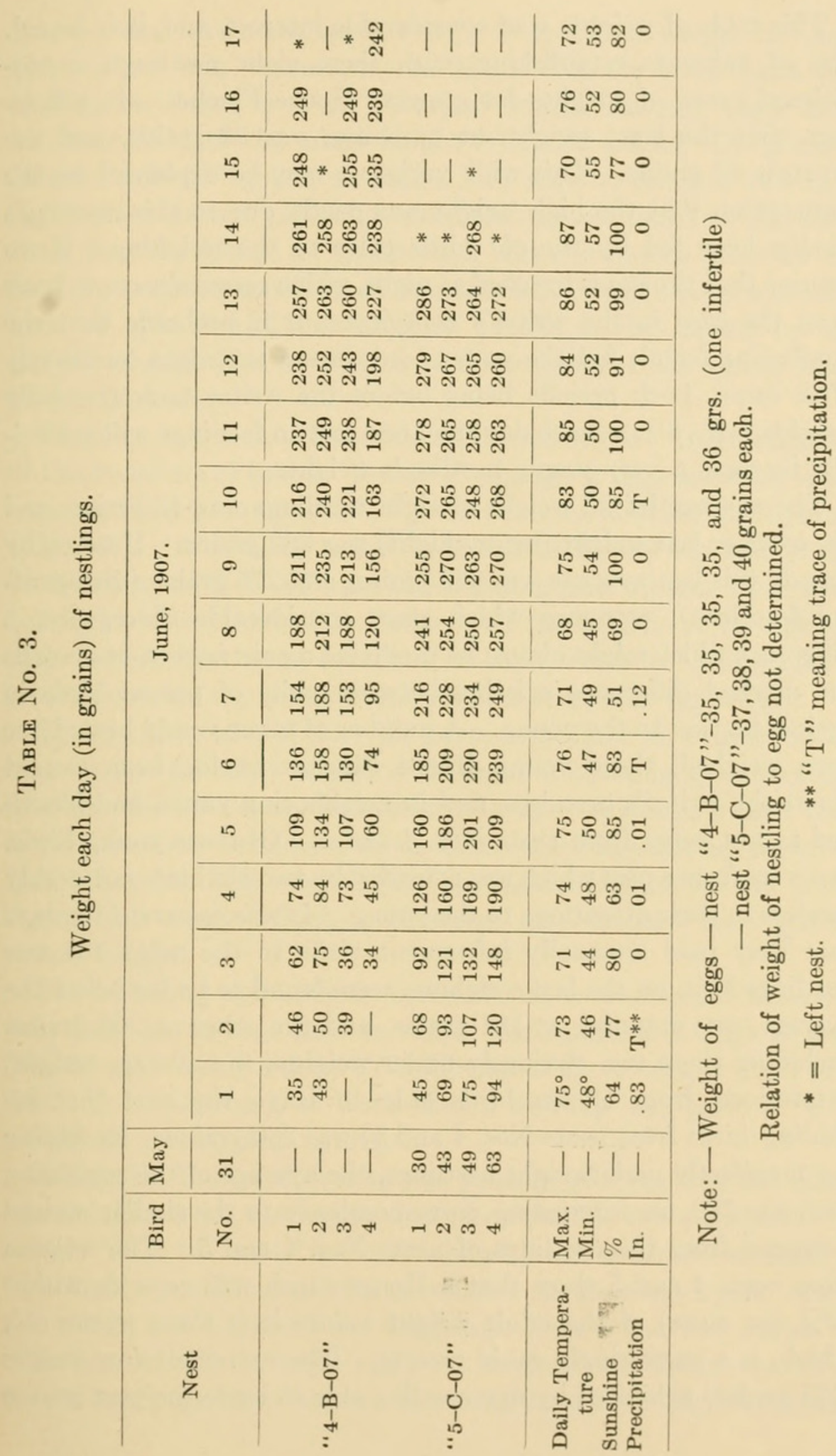


This table of weights is of considerable interest, and, it is hoped, also of value as establishing, with these eight nestlings, a provisional curve of weights for growing House Finches. It will be seen that the least weight, at hatching, was 30 grains, and the greatest 63 grains. This wide variation may be explained on the assumption that the high weight was partly due to this nestling's having been fed by the old birds prior to the weighing. If we assume that the egg is hatched at night, which seems always to have been the case in the writer's experience, it is probable that the incubating female fed the young bird during the night, or shortly after dawn, both periods being before the writer took the daily weights (viz., 8 A. M. each day) and one or two feedings will materially increase a very young nestling's weight.

The average initial weight of eight nestlings was 42 grains, and the average last weight (before flight) was 262 grains. If taken by broods this last average was 249 grains, and 275 grains (disregarding fractions), extremes which show considerable divergence, a difference which might almost be predicted $a$ priori, when one recalls the marked difference existing between pairs of parent birds in their attention to the young. A number of other young birds have been weighed, these young House Finches having been caught about the writer's premises, and in neighboring yards, and identified as not being from nests Nos. 4 and 5. Of these young birds, two were from a nest which was attended by two old birds noticeably careless in their attentions to the young. It was apparent for days that they paid unusually infrequent visits to the nest; the two nestlings in it, on the last weighing, were found to be far below the average, one standing at 181 grains, and the other at 209 grains. Including these two obviously under weights, the average weight, determined from eleven birds able to leave the nest (not including birds from nests Nos. 4 and 5) was 250 grains. Excluding the manifestly underweight nestlings, the average of the remaining nine was 262 , an interesting correspondence to the similar weight averaged from the nestlings of nests Nos. 4 and 5. The weights from nests 4 and 5 show that a House Finch will grow to within $92 \%$ (or more) of the adult weight before it is three weeks old, which, is a surprisingly rapid growth. The extremely low weight (181 grains) exhibited by one nestling able to leave the nest proves 
that a young bird attaining but $62 \%$ of its normal weight can shift for itself, or can, at least, try to do so. On the other hand, one nestling in "nest 5-C-07" reached within thirteen days after hatching $99 \%$ of the adult weight (viz., 289 grains: 286 grains). Brood " $4-\mathrm{B}-07$ " shows us that a bird may be hatched two days before another and yet weigh when leaving the nest but $3 \%$ more than does the latter, an observation which seems to point to the fact that various members of a brood follow very closely a certain level of growth and this level of growth is also shown by the weights of each bird in relation to the weights of the others, when all left the nest.

There is, however, a noticable difference in the "flight weights" of the members of brood " $5-\mathrm{C}-07$," though it appears small when expressed in percentages, i.e., $6 \%$ between the heaviest and lightest (286:268). It is to be noted that this difference occurred in the birds of brood " $5-\mathrm{C}-07$ " notwithstanding that all four birds were hatched within twenty-four hours; and the weights of the various eggs in this nest were too close to each other to presuppose a better start for any given ovum because of greater egg weight.

Toward the close of nest life some birds lose in weight, which may be, and probably is, due to the parents' slacking up on feeding, in their efforts to coax the nestlings to fly. A loss in weight may be due, in some instances, to an alvine discharge having occurred just before the bird was weighed, an incident noted several times during this study. Such a discharge may amount to 5 grains, actual weight.

The following percent gain curve shows, as one would expect, a very large percentage gain in weight during the first days of nest life, the gain then going on a diminuendo scale to zero, or even to a loss. It is surprising to learn that a nestling may gain $60 \%$ in weight in twenty-four hours.

A singular feature shown by the percent gain curve is the spurt upward shown on the fourth day, the mean of the eight birds in broods " $4-\mathrm{B}-07$ " and " $5-\mathrm{C}-07$ " showing this spurt unmistakably. It is highly possible that this peculiarity in the weight gain would not obtain in a large series of weighing. The writer was unable to determine whether a larger egg gives its embryo a better start than does a small egg its embryo. The weights of these eight nestlings 
seem to show that the method of obtaining them had no untoward effect on the growth of the birds. The meteorologic conditions prevailing during the nest life of broods " $4-\mathrm{B}-07$ " and " $5-\mathrm{C}-07$ "

\section{TABle No. 4.}

Average daily gain in weight of eight nestlings, gain given in percent.

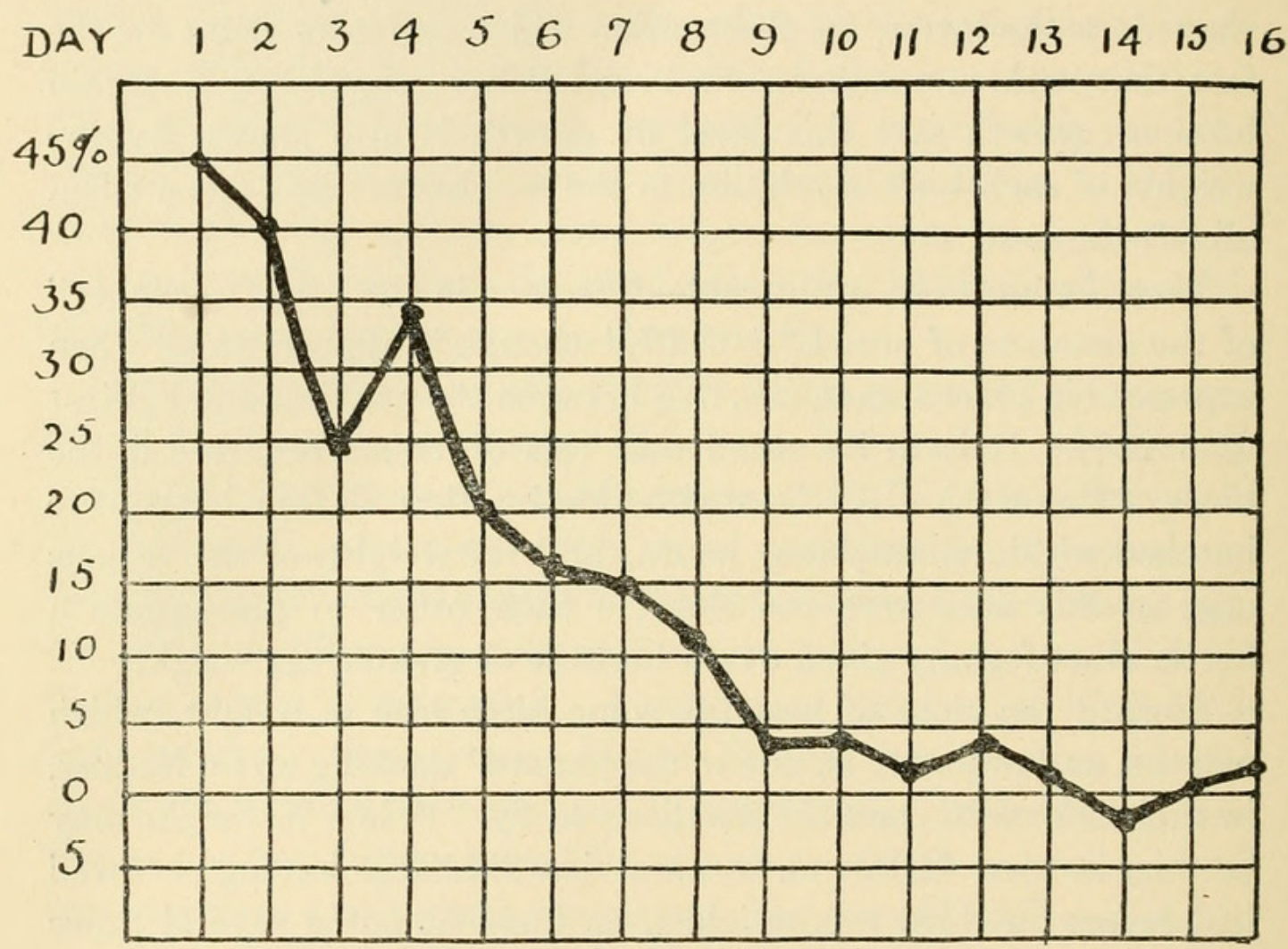

seemed to have little or no influence on the development of the individuals of both broods, though the temperature went, on several nights, below $50 \mathrm{~F}$.

\section{Conclusions as to Weight.}

1. Average weight of House Finch egg - 36 grains.

2. Average weight of newly hatched House Finch - 42 grains.

3. Average weight of young House Finch on leaving nest, 262 grains.

4. Weight of an adult House Finch - 289 grains.

5. Average weight of 17 House Finches (juv.) was $92 \%$ of adult bird's weight.

6. A young House Finch when leaving the nest may weigh within $99 \%$ of the adult weight. 
7. A young House Finch may weigh $99 \%$ of adult weight within two weeks after hatching.

8. A young House Finch may weigh only $62 \%$ of adult weight yet be at large and able to fly about.

9. The House Finch nestlings may lose in weight just before leaving the nest.

\section{Parasites.}

The young and the nests of the House Finch are always infected by a minute parasite, some of which were collected and sent to an entomologist, who determined that they were not true bird lice (Mallophaga) but mites, probably belonging to the family Gamasidæ, subfamily Dermanyssidæ. Further than this, no study of the House Finches' dermal parasites has been made.

\section{Albino House Finch.}

On March 12, 1907, the writer and his family observed a snow white House Finch, which was evidently a female as it was plainly mated to a normal male which accompanied it. This albino was entirely white except a suspicion of dusky encircling the base of both mandibles. Another albino female House Finch was seen the next year in a neighbor's yard. It was assumed to be the one observed the previous year.

\section{INJURIES.}

The propinquity of this species at the office and house has permitted such close observation that many of these bird visitors have become known by deformities which they had sustained from injuries; a surprisingly large number of crippled House Finches has been noted, none of which seemed to be any the worse for its handicap. Eleven crippled House Finches exhibited the following mutilations or deformities:

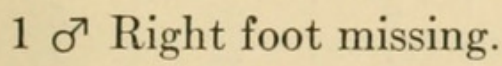

1 ㅇ Right leg missing,

$1 \sigma^{\top}$

$2 \sigma^{\top} \sigma^{7}$ Left “ “ “

1 o One foot and one-half of tarsus missing, 
1 우 Left tarsus and foot crippled and drawn up.

1 ๙ Right foot permanently doubled up.

1 ऽ Left leg paralyzed.

1 o With crooked leg,

1 б Right tarsus bent.

Every one of these aforesaid birds was well nourished, and seemingly quite able to care for itself. Those with but one leg were a little awkward in perching on the drinking dish, or food tray, as were also those with markedly deformed legs or feet. One with but one half a tarsus on one side used it as a stump, and did so with ease and agility. It is rather difficult to explain these mutilations; the most reasonable explanation being that the missing members were lost by being frozen. In extremely cold weather this species does suffer from cold feet, and it has frequently been seen standing on one foot while warming the other drawn up in its feathers. These crippled birds prove that considerable mutilation may occur with a wild House Finch, without soon eliminating it in the struggle for existence.

\section{Mortality.}

The following tabulation shows the ultimate fate of all the eggs laid in the nests under observation:

Table No. 5 .

\begin{tabular}{|c|c|c|c|c|c|c|c|}
\hline \multirow{2}{*}{$\begin{array}{c}\text { Result } \\
\text { Year }\end{array}$} & \multicolumn{5}{|c|}{ Cause of loss:- By } & \multirow[b]{2}{*}{$\begin{array}{c}\text { Young } \\
\text { fly }\end{array}$} & \multirow[b]{2}{*}{ Total } \\
\hline & 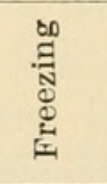 & 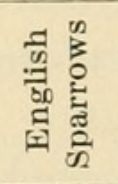 & 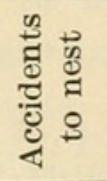 & 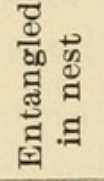 & 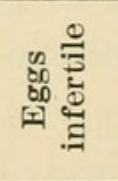 & & \\
\hline 1906 & 0 & 6 & 4 & 0 & 1 & 22 & 33 \\
\hline 1907 & 13 & 2 & 2 & 1 & 8 & 38 & 64 \\
\hline 1908 & 15 & 18 & 5 & 0 & 3 & 46 & 87 \\
\hline 1909 & 1 & 9 & 4 & 0 & 9 & 29 & 52 \\
\hline 1910 & 0 & 10 & 2 & 0 & 4 & 31 & 47 \\
\hline Total & 29 & 45 & 17 & 1 & 25 & 166 & 283 \\
\hline$\%$ & $10 \%$ & $16 \%$ & -6 & $6-$ & $9 \%$ & $59 \%$ & \\
\hline
\end{tabular}


Counting fertile eggs and hatched young as potential additions to our House Finch population, we find that the mortality is very large with this species, even if estimated only to include the first four weeks after the eggs are laid.

Over forty percent of the eggs laid were ultimate failures, the largest factor in the loss being destruction of the eggs and young by the English Sparrow, a condition to be considered shortly. About ten percent loss is caused by late spring storms, climatic conditions lasting but a short time, yet long enough to cause that much loss. There are a few minor accidents which have been recorded during this study: thus one nestling perished because it could not be, or was not, freed from the sticky egg shell; another became entangled in the fibrous nesting material, and, unable to leave the nest when full grown, was abandoned by the old birds; once a box was blown down and the eggs destroyed by the fall. One young bird, recognized by its brass anklet, was found crushed in the street the same day it left the nest.

\section{English Sparrow vs. House Finch.}

There remains at least one point in the data accumulated during this study of the House Finch, which, while not relating wholly to it is of so much importance in relation to its future that it rightfully must be examined here. The question is, namely, the relation of the House Finch to the English Sparrow.

Cooke suggested (Birds of Colorado, March, 1897) that this sparrow in its westward march would perhaps "meet its first real foe" in Colorado in the House Finch. The information gathered in this study will shed some light on this question, which must be examined not only concerning the contact of adult forms, but also with regard to the nesting habits, fertility, etc. The relative length of the nesting and breeding periods is of first importance. In Denver English Sparrows are commonly seen fighting each other for nesting sites in November, December and January, and the earliest date when this sparrow has been noticed taking up material for a nest, was January 8, on which date a pair of English Sparrows was seen breeding; and also by this time of the year completed nests have often been observed. While both House Finch and 
English Sparrow seem stimulated to mating and nesting by mild warm weather, yet the second species seems much more susceptible to this stimulus, and responds much earlier. At the other extreme of the year parallel conditions obtain: The House Finch has never been seen, by the writer, building a nest or having eggs in one, after August, while the English Sparrow habitually continues egg laying and incubation during this month, in September, and fresh eggs of this species have been taken during the third week in October. It would thus appear that the English Sparrow's season of nidification extends throughout almost the entire year, exceeding that of the House Finch by many weeks. It thus is apparent that the English Sparrow gets its young into the field earlier and during a much longer period than does the House Finch, which, in itself, would almost certainly cause it to win against the House Finch in a struggle between the two species. The male English Sparrow does as much of the nest building as its mate, while the male House Finch does nothing in this way to help its mate, a difference which may hasten and facilitate the completion of an English Sparrow's nest in a shorter time than that of the House Finch.

The Sparrow's large bulky nest, wherever situated, with its usual lining of feathers, is far more resistant to snow or rain than is the open Finch nest, another factor tending to promote the multiplication of the English Sparrow, under conditions in which the young House Finches perish. The English Sparrow's greater adaptability is also in its favor. This flexibility of nesting exhibited by the English Sparrow comes into prominence in its habit, in Denver, of using abandoned nests of Bullock's Oriole (I. bullocki) in which to raise its young.

The loss of nests, eggs and young of the House Finch through direct destruction by the English Sparrow is very large. It was $16 \%$ in some of the nests studied by the writer, and, moreover, this $16 \%$ loss of eggs does not include the very large potential loss of House Finch eggs and young brought about by destruction of nests by English Sparrows before the House Finch eggs are laid in them. One should remember also that there must be a loss of House Finches greater than $16 \%$ through the English Sparrows when they are not prevented from harassing the House Finch. 
Sixteen percent of the eggs and young of the House Finch were lost on the writer's premises through destruction by the English Sparrow, notwithstanding the writer's constant and persistent attempts to destroy the latter species in his neighborhood. The writer has personally witnessed English Sparrows going into the House Finches' nests, and has seen them throw out the young, these nestlings having the heads pecked open by the Sparrows before they were thrown out. The House Finch will often put up a mild fight against the invaders, giving at the same time a very characteristic squeak but the Finch is almost invariably beaten in these battles. In many years' observations on this phase of the Finch question, the writer has but once seen a Finch whip a Sparrow. In the early years of this study, before it was undertaken systematically, the writer lost a great many nests, eggs and young of the House Finch through the depredations of the English Sparrow, and despite many and various schemes to drive away the English Sparrow and help the House Finch, he did not succeed until a powerful air gun was secured, with which the Sparrows were finally decimated in his neighborhood.

The first English Sparrows seen in Denver by the writer were noted at the Union Depot in 1894, and then a few pairs only. Today, the writer believes, there are in this city, estimating along lines similar to those used in estimating the House Finch (comparing numbers for numbers) more than one half a million English Sparrows.

It would thus seem self-evident that this exotic sparrow has flourished in Denver since 1894, and has been in no way prevented by the House Finch from increasing. On the contrary, the evidence gathered by the writer is overwhelming that the English Sparrow overcomes, and is superior to, the House Finch in the biologic struggle. That it is the winner in this fight, many of our citizens realize; but they do not realize that it brings about a retardation of the spread of a native species, whose help to the community as a weed destroyer is of far greater value than is any benefit accruing from the English Sparrow as a scavenger, or through its habit of feeding its nestlings partly on animal food. 


\section{$2 \mathrm{BHL}$ Biodiversity Heritage Library}

Bergtold, W. H. 1913. "A Study of the House Finch." The Auk 30, 40-73. https://doi.org/10.2307/4071894.

View This Item Online: https://www.biodiversitylibrary.org/item/54992

DOI: https://doi.org/10.2307/4071894

Permalink: https://www.biodiversitylibrary.org/partpdf/89259

\section{Holding Institution}

Smithsonian Libraries

\section{Sponsored by}

Smithsonian

\section{Copyright \& Reuse}

Copyright Status: Public domain. The BHL considers that this work is no longer under copyright protection.

This document was created from content at the Biodiversity Heritage Library, the world's largest open access digital library for biodiversity literature and archives. Visit BHL at https://www.biodiversitylibrary.org. 